\title{
The Pampulha reservoir remains a potential urban focus of schistosomiasis mansoni in Brazil: changes in the occurrence patterns of Biomphalaria species and a new record of the parasite
}

\author{
Hudson Alves Pinto ${ }^{[1]}$, Vitor Luís Tenório Mati ${ }^{[1]}$ and Alan Lane de Melo ${ }^{[1]}$
}

[1]. Laboratório de Taxonomia e Biologia de Invertebrados, Departamento de Parasitologia, Instituto de Ciências Biológicas, Universidade Federal de Minas Gerais, Belo Horizonte, MG.

\begin{abstract}
Introduction: The Pampulha reservoir has long been a focus of schistosomiasis transmission in Belo Horizonte, State of Minas Gerais, Brazil. The last malacological study conducted in this urban reservoir was more than two decades ago, and thus, an update on the distribution of the species of Biomphalaria as well as new data on the presence of Schistosoma mansoni in this water body are required. Methods: The current distribution of Biomphalaria spp. in the Pampulha reservoir and their infection with S. mansoni was evaluated during 55 malacological surveys conducted between 2009 and 2012. Results: Biomphalaria straminea displayed a high population density and distribution, and 13.7\% $(2,233 / 16,235)$ of the specimens collected were infected with larval trematodes other than Schistosoma mansoni. Biomphalaria tenagophila and Biomphalaria glabrata, species currently presenting a restricted distribution and small populations, displayed trematode infection rates of $15.2 \%(98 / 644)$ and $13 \%$ (83/640), respectively. Thirteen (2\%) specimens of B. glabrata were found to be infected with $S$. mansoni. In addition, a historical review based on previous and new data on the occurrence patterns of Biomphalaria species in this reservoir is presented. Conclusions: The results indicate that the Pampulha reservoir remains a potential focus of urban schistosomiasis in Brazil, and significant changes in the occurrence patterns of Biomphalaria species were verified.
\end{abstract}

Keywords: Schistosomiasis. Snails. Cercaria. Urban lake. Tourism. Minas Gerais.

\section{INTRODUCTION}

Schistosomiasis mansoni is a helminth disease that affects approximately 6 million people in Brazil ${ }^{1}$ and was previously considered a disease typically endemic in rural areas. However, in recent decades, mainly due to human migration, a change has occurred in the transmission pattern of this parasite, as observed in different metropolitan areas of the country ${ }^{2-5}$. With the goals of eliminating active transmission foci and preventing outbreaks of schistosomiasis in urban areas from Brazil, the monitoring of molluscan transmitters of Schistosoma mansoni Sambon, 1907, is an important aspect of epidemiological surveillance of the disease ${ }^{6}$.

The Pampulha reservoir is one of the first urban foci of schistosomiasis in Brazil. The reservoir was built in the late 1930s, and its architectural complex is still one of the main tourist attractions in Belo Horizonte, which is the capital of the State of Minas Gerais in southeastern Brazil. This water body

Address to: Hudson Alves Pinto. Laboratório de Taxonomia e Biologia de Invertebrados/Dept ${ }^{\mathfrak{o}}$ de Parasitologia/ICB/UFMG. Caixa Postal 486, 30123-970 Belo Horizonte, MG, Brasil.

Phone: 5531 3409-2978

e-mail: hudsonalves13@ig.com.br

Received 8 May 2013

Accepted 10 July 2013 was initially intended to serve as a water supply and to capture runoff from rainfall, but it has become an important area for recreational activities, which has contributed to the emergence of a schistosomiasis focus in Belo Horizonte. The first record of snails that were naturally infected with $S$. mansoni in the Pampulha reservoir was reported by Martins and Versiani ${ }^{7}$, who observed that Biomphalaria glabrata (Say, 1818) was infected with this trematode. These same authors conducted a coproparasitological survey of individuals who frequented the reservoir and uncovered an outbreak of schistosomiasis. In fact, this reservoir contributed to the increase of the prevalence of the disease in the capital of Minas Gerais from $0.5 \%$ in $1920^{8}$ to $11.7 \%$ in $1938^{\circ}$. Approximately three decades later, Paulini et al. ${ }^{10}$ obtained positive parasitological results from $18.7 \%$ of local residents in the same region. Given the presence of a transmission focus of schistosomiasis in the reservoir, several malacological studies that emphasize planorbids were also conducted at the Pampulha reservoir ${ }^{11-17}$. However, the latest published information dates to more than two decades ago; thus, an update is required.

\section{METHODS}

Malacological surveys were conducted at the margins of the Pampulha reservoir (19 $\left.9^{\circ} 1^{\prime} \mathrm{S}, 43^{\circ} 58^{\prime} \mathrm{W}\right)$, Belo Horizonte, State of Minas Gerais, Brazil, between January 2009 and November 2012. This reservoir has an amoeboid shape and is situated at 
an altitude of $810 \mathrm{~m}$. The reservoir is formed by the impounding of eight streams (AABB, Água Funda, Baraúnas, Mergulhão, Olhos D'água, Ressaca, Sarandi and Tijuco) that drain within the metropolitan region of Belo Horizonte. Although the Pampulha reservoir had a water volume of $18 \mathrm{million} / \mathrm{m}^{3}$ and a $21 \mathrm{~km}$ perimeter at the time of its construction, the current volume is approximately $10 \mathrm{million} / \mathrm{m}^{3}$, with a maximum depth of $13.3 \mathrm{~m}$ and a perimeter of $14 \mathrm{~km}$. This reduction has primarily resulted from silt accumulation, mainly due to the discharge of untreated sewage into the reservoir, which since the 1970s has contributed to the current state of eutrophication, and phenomena such as algal blooms and the proliferation of aquatic macrophytes are commonly observed ${ }^{18-19}$, factors that contribute to the establishment of high densities of snails in this water body.

Six convenience sampling points (Figure 1) were selected without the use of any theoretical approach but, rather, based on criteria such as facility access to margins of the reservoir and previous reports of the occurrence of populations of snails. However, the sampling points where the largest numbers of samples (sampling points 1 and 4) were collected are relatively distant from each other (approximately $3.5 \mathrm{~km}$ ) and are at opposite ends of the reservoir. Sampling was conducted without defined periodicity; however, considering all sampling points, the average interval between sampling was one month. In total, $25,3,5,14,4$ and 4 malacological samples were collected at sampling points 1 to 6 , respectively. Each field excursion at each sampling point was counted once, for a total of 55 samples.

Snails were collected with the aid of a D-shaped nylon hand net $\left(50 \mathrm{~cm}\right.$ wide and $40 \mathrm{~cm}$ high with a $30 \mathrm{~cm}$ opening and $1 \mathrm{~mm}^{2}$ mesh) for $60 \mathrm{~min}$ of sampling effort, spanning approximately $100 \mathrm{~m}$ at each sampling point. The collected material was transferred to plastic bags, labeled and transported to the laboratory, where the snails were separated and individually placed in microtiter plates containing $3 \mathrm{ml}$ of chlorine-free water. The snails were then exposed to artificial photostimulation for two hours and examined under a stereomicroscope for the presence of larval trematodes. A new examination of snails was performed on the day after collection before and after photostimulation. The cercariae obtained were studied under a light microscope with the aid of vital stain $(0.05 \%$ neutral red), and those trematodes with morphology consistent with $S$. mansoni were used to experimentally infect groups of five mice via the subcutaneous route (100 cercariae/animal). Stool examinations were conducted using the spontaneous sedimentation technique ${ }^{20} 40$ days after inoculation with cercariae, and perfusion of the hepatic portal system was performed 60 days after infection ${ }^{21}$. Specimens of the planorbids were killed in water at $70^{\circ} \mathrm{C}$ and processed according to Deslandes ${ }^{22}$ for taxonomic identification, which was based on morphological criteria according to Paraense ${ }^{23}$. In addition, a historical review of the occurrence patterns and distribution of Biomphalaria species at the sampling points was performed to emphasize the main changes in these parameters over the history of the Pampulha reservoir.

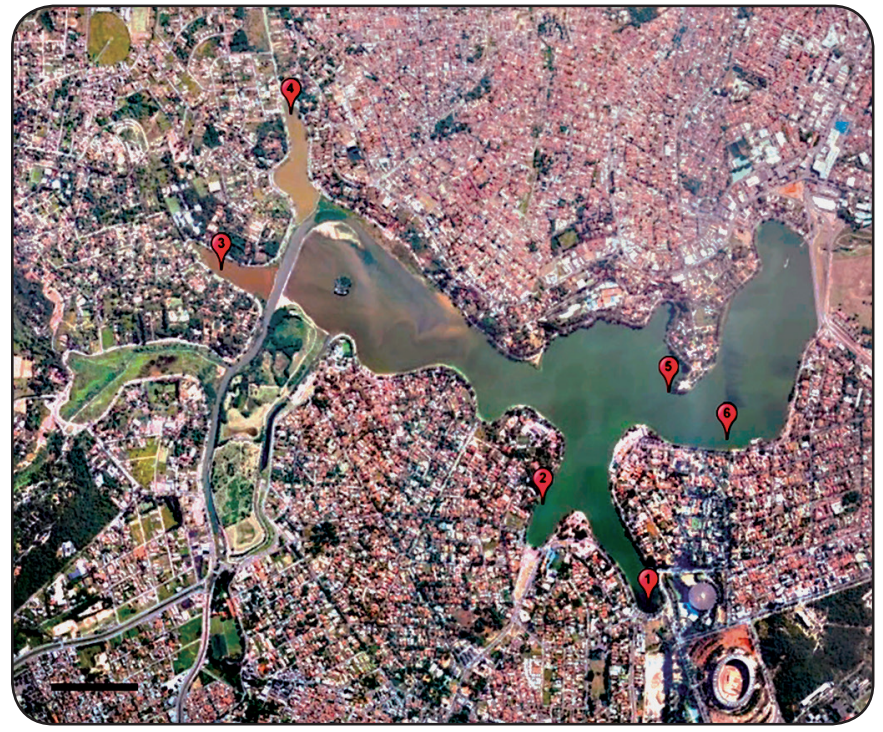

FIGURE 1 - Current map of the Pampulha reservoir, Belo Horizonte, State of Minas Gerais, Brazil, and the six sampling points where malacological surveys were performed between January 2009 and November 2012. Scale bar: 500m. Source: Google Earth.

\section{RESULTS}

During the malacological samplings performed in the Pampulha reservoir, 17,519 specimens of Biomphalaria spp. were collected. Of these, 2,514 (14.4\%) were infected with 14 non-S. mansoni larval trematodes species belonging to different cercarian types, including brevifurcate, clinostomatoid, echinostome, gymnocephalous, magnacauda, monostome and strigea cercariae, which were subjected to taxonomic and life cycle studies. The three species of snails with epidemiological importance in the transmission of S. mansoni in Brazil, namely, B. glabrata, Biomphalaria tenagophila (d' Orbigny, 1835) and Biomphalaria straminea (Dunker, 1848), are currently present in the Pampulha reservoir. However, the distribution of these planorbid snails in the areas evaluated is markedly different from that observed during malacological surveys previously performed by other authors. A representation of changes in the species distribution of the intermediate hosts of $S$. mansoni at the Pampulha reservoir over more than seven decades is shown in Figure 2.

Currently, B. straminea is the species with the highest population density and distribution in the Pampulha reservoir. It was the only species of planorbid verified at all sampling points. From 16,235 specimens $(92.8 \%$ of the total of the snails examined), 2,233 (13.7\%) were observed to harbor larval trematodes other than S. mansoni. Biomphalaria tenagophila had a restricted distribution and was found primarily in small populations at sampling points 3 and 4 . Infection rates of $15.2 \%(98 / 644)$ were observed for larval trematodes other than S. mansoni. Biomphalaria glabrata also displayed a restricted distribution primarily in a low population density at sampling point 4 . A total of $13 \%(83 / 640)$ of B. glabrata evaluated were infected with larval trematodes, and $13(2 \%)$ specimens of this 


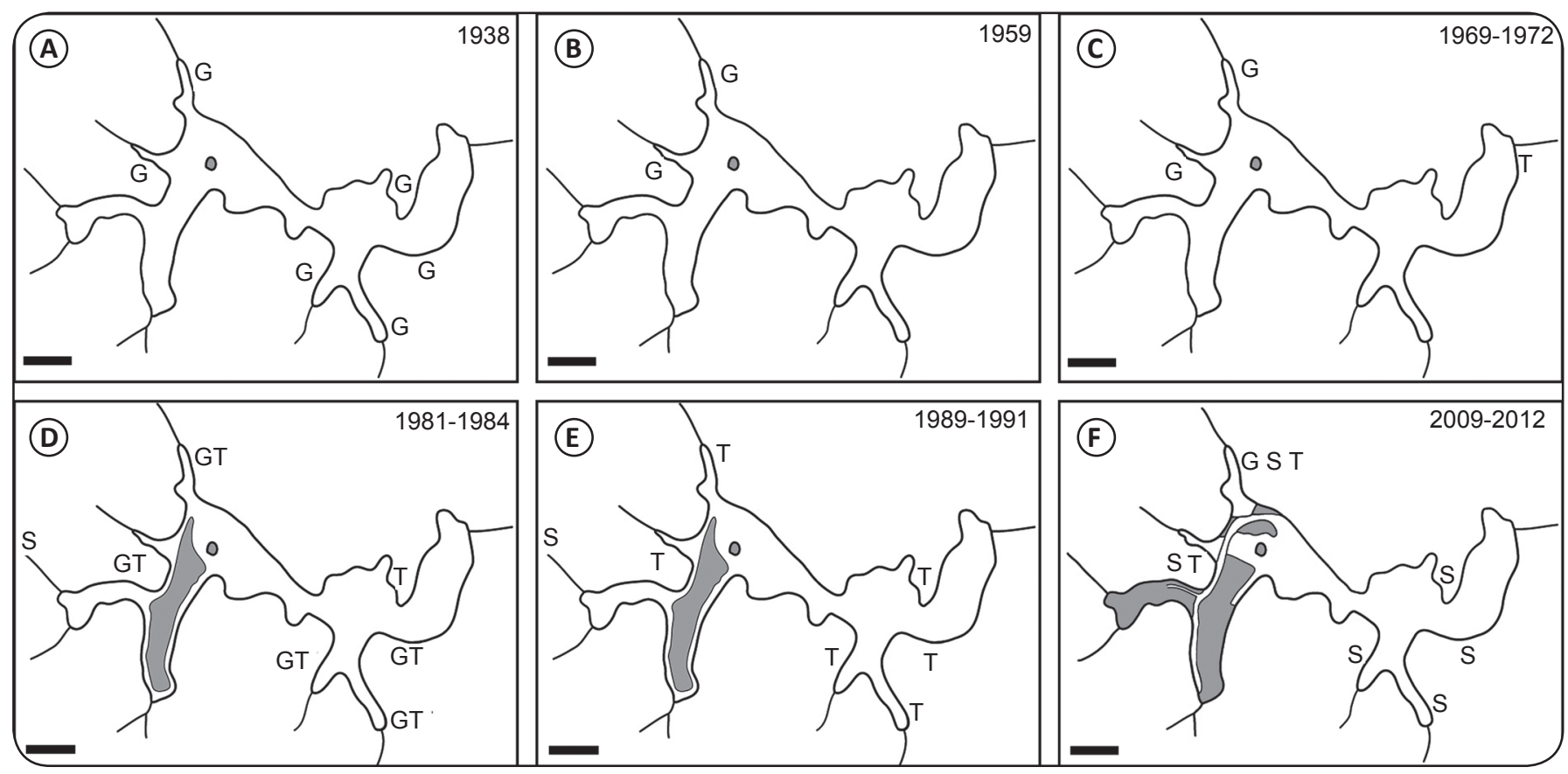

FIGURE 2 - Sketch maps of the Pampulha reservoir, Belo Horizonte, State of Minas Gerais, Brazil, showing the distribution of the Biomphalaria species in the six sampling points evaluated during the present and previous malacological surveys by other authors at different times. The sites of introduction of Biomphalaria tenagophila and Biomphalaria straminea are also indicated with the corresponding dates. A: 1938 (Martins \& Versiani 1939; B: 1959 (Milward-de-Andrade 1959); C: 1969-1972 (Milward-de-Andrade 1969, 1972); D: 1981-1984 (Carvalho et al. 1985); E: 1989-1991 (Freitas et al. 1992, Freitas \& Santos 1995); F: 2009-2012 (present study). Abbreviations: G: Biomphalaria glabrata, S: Biomphalaria straminea, T: Biomphalaria tenagophila. Scale bars: $500 \mathrm{~m}$. The gray areas represent islands or areas of silt accumulation.

species harbored $S$. mansoni larvae. This parasite was present in samples collected over the three years evaluated, with an average infection percentage of $2.5 \%$ (from 1.5 to $11.1 \%$ ). At sampling point 4, where $B$. glabrata were observed in the Pampulha reservoir, the cercariae of $S$. mansoni were verified in $35.7 \%(5 / 14)$ of the sampling dates. Adult parasites of both sexes were recovered from mice that were experimentally infected with cercariae that emerged from naturally infected B. glabrata, and the eggs of the parasite were observed in the feces of the rodents 40 days after infection. The morphology of cercariae and adult trematodes were similar to those reported for other strains of $S$. mansoni.

\section{DIscussion}

Although methodological differences (e.g., malacological field methods, number of samples and duration of the studies) may make it difficult to compare the previous malacological studies performed at the Pampulha reservoir, the data shown in the present study, including those relating to the historical review of occurrence patterns and distribution of Biomphalaria species at the sampling points, suggest that changes most likely occurred in the distribution of the species in recent decades, as discussed below.

Biomphalaria straminea is a widely distributed species in Brazil, and among the intermediate hosts of S. mansoni, it is the least susceptible but is responsible for maintaining schistosomiasis in some endemic areas in the northeast region of the country. Although their current relevance in the transmission of the parasite in southeastern and west-central Brazil appears to be minimal, the presence and growth of $B$. straminea in localities from these regions around Brazil are associated with environmental and social changes related to the epidemiology of schistosomiasis and should serve as a warning. It is possible that this species may become epidemiologically important in the transmission of parasites in these regions in the future ${ }^{24-27}$. This species was first reported in Belo Horizonte at the Pampulha basin (in the Baraunas stream) in the early $1980 \mathrm{~s}^{28}$, and until the early 1990s, it remained restricted to the introduction site and was not verified within the reservoir ${ }^{29}$. However, since the mid1990s, the species has been found inside the Pampulha reservoir near sampling point 2 (Dr. Alan Lane de Melo, unpublished results). The data obtained in the present study demonstrate that $B$. straminea is currently found at all sites evaluated, often with a high population density. Furthermore, $B$. straminea was the only species found in places previously colonized by $B$. tenagophila and/or B. glabrata, as reported by Carvalho et al..$^{15}$ and Freitas et al. ${ }^{17}$. Determining the factors related to the replacement and current distribution of $B$. straminea will require additional studies. Regarding the experimental susceptibility of $B$. straminea, which originated from the Baraunas stream, to $S$. mansoni, Souza et al..$^{30}$ found infection rates ranging between $5.7 \%$ and $19 \%$. However, thus far, B. straminea that are naturally infected with $S$. mansoni have not been observed in the Pampulha reservoir. In contrast, the cercariae of avian schistosomes, which may be involved in cases of cercarial dermatitis in humans, were recently reported in B. straminea collected from this reservoir ${ }^{31}$. 
Biomphalaria tenagophila displays intermediate susceptibility to $S$. mansoni and is responsible for maintaining the disease in some regions as well as isolated foci in southeastern Brazil. This species was originally reported at the Pampulha reservoir by Milward-de-Andrade ${ }^{14}$ and soon became the predominant planorbid species in the locality, occupying the entire edge of the reservoir between the early $1980 \mathrm{~s}$ and the $1990 \mathrm{~s}^{15,17,29}$. This species of Biomphalaria was observed to be infected with S. mansoni at a very low rate, $0.03 \%(1 / 3,695)$, in the Pampulha reservoir by Carvalho et al. ${ }^{15}$. Later, Souza et al. ${ }^{32}$ reported two specimens that were naturally infected by the parasite but did not provide an infection rate. Data from experimental infection of B. tenagophila originating from the Pampulha reservoir with different strains of $S$. mansoni revealed infection rates ranging between 4 and $68 \% \%^{32-35}$; however, the sampling conducted during the present study revealed that this planorbid species was not verified to be infected with this parasite.

Biomphalaria glabrata is the snail species acting as an S. mansoni transmitter with the greatest epidemiological importance in Brazil given its wide distribution and high susceptibility to the parasite. After the finding of S. mansoni in B. glabrata in the Pampulha reservoir in the 1930s, the reservoir was temporarily emptied, which resulted in the elimination of approximately 15 million specimens of $B$. glabrata. Since then, the species has been found in the reservoir with low population densities but continues to harbor larvae of $S$. mansoni $i^{11-13,15,28}$. In the early 1990 s, B. glabrata was considered absent from the reservoir, although the species was present in tributary streams, and it was suggested that the occasional findings of this species in the reservoir resulted from snails carried by rainfall runoff ${ }^{17,29}$.

However, the results obtained in the present study suggest that a population of B. glabrata was established at sampling point 4 of the reservoir, considering that specimens of this planorbid species of different sizes were collected and that specimens infected with $S$. mansoni were common in the dry seasons of the three years evaluated. Thus, B. glabrata not only remains present in the Pampulha reservoir but is also still infected with $S$. mansoni. The infection rates of B. glabrata with $S$. mansoni obtained in this study are consistent with those found in other endemic areas and are generally higher than those reported for this same species in the Pampulha reservoir, including $0.6 \%(1 / 176)$ by Martins and Falcão ${ }^{11}$ and $0.5 \%(2 / 467)$ by Carvalho et al. ${ }^{15}$. Only in the pioneering study of Martins and Versiani $(2.4 \%, 1 / 42)^{10}$ and the results reported by Souza et al. $(3.5 \%, 2 / 57)^{28}$ were the rates of infection of B. glabrata by $S$. mansoni similar to that observed in the present study. Regarding the experimental susceptibility to $S$. mansoni, infection rates of $30 \%$ and $59 \%$ were obtained in B. glabrata from the Pampulha reservoir ${ }^{36}$.

The factors related to changes in the distribution of Biomphalaria species in association with the natural history of the Pampulha reservoir require additional studies. Several authors have reported the possible natural competition or coexistence between Biomphalaria species in Brazil ${ }^{29,37-41}$. It is interesting to note the unusual serial replacement of predominant species of snail intermediate hosts of S. mansoni.
Initially, B. glabrata predominated in this reservoir. However, this species was replaced by $B$. tenagophila, and subsequently, $B$. straminea became the predominant species. The replacement of B. tenagophila by B. straminea is reported here for the first time. These observations reflect the possible occurrence of interspecific competition between these species. In fact, the competition and elimination of B. glabrata by B. straminea has been reported in experimental and natural conditions ${ }^{38,40-42}$, and we cannot rule out the possibility that the competitive advantages of $B$. straminea also exist with respect to $B$. tenagophila. However, the factors related to the overlap of one species of snail over another are complex, and changes in the environment appear to have great importance ${ }^{17}$. Indeed, the continuous increase in the eutrophication status of the reservoir over the past decades, as indicated by the deterioration of water quality indicators ${ }^{17,19}$, may have made the water of the Pampulha reservoir unfavorable for the maintenance of B. tenagophila at most sampling points where this species is no longer observed.

The occurrence of two species of Biomphalaria with epidemiological importance in the transmission of schistosomiasis in the same body of water is rare and has been verified mainly in urban environments ${ }^{29}$. However, unlike previous reports, all three species of snails that transmit $S$. mansoni were observed in the Pampulha reservoir during this study. In fact, the coexistence of these three species of Biomphalaria, although only at sampling point 4 , has not been previously reported. This specific sampling point presents distinct features compared to the other points, primarily because it is located near the top of one of the tributary streams and therefore has a greater flow of water. In fact, the occurrence of B. glabrata at this sampling point has been reported since the late $1950 \mathrm{~s}^{12}$. In addition, some factors related to water quality, such as conductivity and oxygen, phosphorus, ammonia, nitrite, nitrate and chlorophyll levels, have different values when compared to the other sampling points ${ }^{19}$, but the true influence of these variables on the results obtained remains unknown. In addition, the influence of recent anthropogenic changes on the reservoir, which have partially isolated some areas of the water, have contributed, at least in part, to the reservoir becoming an environmentally unstable habitat.

Regarding the possible biological competition between the vectors of S. mansoni and other species of snails (Pomacea sp. and Melanoides tuberculata), several studies have been conducted on the Pampulha reservoir ${ }^{12,16,17,29}$. However, over more than three decades of coexistence between these species in the Pampulha reservoir, the presence of these potential competitors has not eliminated the populations of Biomphalaria spp. or, consequently, the focus of transmission. In fact, high populations of these prosobranchs remain at the locality (data not shown), which appears to have no noticeable effect on the current population of Biomphalaria species or on the epidemiology of schistosomiasis in the locality, which has also been recorded in other eutrophic and unstable environments where food for the snails is widely available ${ }^{43,44}$.

A high percentage of snails infected with the larvae of other trematode species was found during the malacological surveys in the present study. These findings are mainly the result of 
factors such as the large densities of second intermediate hosts (fish) and definitive hosts (mostly birds) currently observed in the reservoir due its high eutrophication state. Although some species of these trematodes may have antagonistic relationships with the Biomphalaria snails and direct relationships with S. mansoni ${ }^{45,46}$, the effects of their presence on the transmission of $S$. mansoni are, as of yet, poorly studied in Brazil.

The source of infection of $S$. mansoni for the snails in the Pampulha reservoir is most likely related to the direct discharge of untreated sewage into its interior, which can contain feces of humans infected with the parasite. Human cases of schistosomiasis have been registered in the metropolitan region of Belo Horizonte, including recent outbreaks related to rural and ecological tourism ${ }^{3,47-50}$. Although the Pampulha reservoir remains a place for recreational activities, its contribution to maintaining the prevalence of schistosomiasis in Belo Horizonte is low given that its poor water quality discourages people from coming into contact with it. Thus, the risk of the Pampulha reservoir becoming an active focus of schistosomiasis transmission under the current conditions is attenuated but still persists because the margins of this reservoir are frequented by fishermen, who often come into contact with the water.

The implementation of measures to revitalize the Pampulha reservoir has been discussed over the last decade ${ }^{19,51,52}$. In this context, any action taken to improve the conditions currently found in this urban reservoir should consider the presence of S. mansoni-transmitting mollusks. It is necessary to be alert to these dangers so that the Pampulha reservoir does not return to being an active urban focus of schistosomiasis in Brazil. Furthermore, studies must be performed to elucidate the phenomena involved in the substitution of one species of snail host of $S$. mansoni for another in a given aquatic collection.

\section{CONFLICT OF INTEREST}

The authors declare that there is no conflict of interest.

\section{FINANCIAL SUPPORT}

\section{CNPq - Conselho Nacional de Desenvolvimento Cientifico} e Tecnológico.

\section{REFERENCES}

1. Katz N, Peixoto SV. Análise crítica da estimativa do número de portadores de esquistossomose mansoni no Brasil. Rev Soc Bras Med Trop 2000; 33:303-308.

2. Kloos H, Correa-Oliveira R, Quites HFO, Souza MCC, Gazzinelli A. Socioeconomic studies of schistosomiasis in Brazil: A review. Acta Trop 2008; 108:194-201.

3. Enk MJ, Amaral GL, Silva MF, Silveira-Lemos D, Teixeira-Carvalho A, Martins-Filho OA, et al. Rural tourism: a risk factor for schistosomiasis transmission in Brazil. Mem Inst Oswaldo Cruz 2010; 105:537-540.

4. Barbosa CS, Leal-Neto OB, Gomes ECS, Araújo KCGM, Domingues ALC. The endemisation of schistosomiasis in Porto de Galinhas,
Pernambuco, Brazil, 10 years after the first epidemic outbreak. Mem Inst Oswaldo Cruz 2011; 106:878-883.

5. Souza SS, Barbosa LM, Guimarães IC, Blank WA, Reis RB, Reis MG, et al. Genetic population structure of cercariae from an urban foci of Schistosoma mansoni, Brazil. Am J Trop Med Hyg 2012; 87:843-849.

6. Amaral RS, Thiengo SC, Pieri OS (eds). Vigilância e Controle de Moluscos de Importância Epidemiológica: Diretrizes Técnicas: Programa de Vigilância e Controle da Esquistossomose (PCE), $2^{\text {nd }}$ ed. Brasília: Editora Ministério da Saúde; 2008.

7. Martins AV, Versiani W. Schistossomose mansoni em Belo Horizonte. Braz Med 1938; 52:471-472.

8. Melo-Teixeira J. A schistosomose mansônica na infância em Belo Horizonte. Imprensa Oficial: Belo Horizonte; 1919.

9. Martins AV, Versiani W. Plano de combate à schistossomose mansoni em Belo Horizonte. O Hospital 1939; 15:187-206.

10. Paulini E, Dias EP, Fiúza H. Contribuição a epidemiologia da esquistossomose em Belo Horizonte. Rev Bras Mal Doenças Trop 1967; 19:571-606.

11. Martins AV, Falcão AL. Distribuição geográfica dos planorbídeos e seus índices de infestação pelas cercárias de Schistosoma mansoni no município de Belo Horizonte. In: Congresso Brasileiro de Higiene, 10, Curitiba; 1953.

12. Milward-de-Andrade R. O problema da esquistossomose mansoni no lago artificial da Pampulha, Belo Horizonte, Minas Gerais (Brasil). Rev Bras Mal Doenças Trop 1959; 11:653-674.

13. Milward-de-Andrade R. Nota ecológica sôbre o lago da Pampulha (Belo Horizonte, MG). Com especial referência aos planorbídeos (Pulmonata, Planorbidae). Rev Bras Mal Doenças Trop 1969; 21:59-116.

14. Milward-de-Andrade R. Primeiro encontro de Biomphalaria tenagophila (d'Orbigny, 1835) no lago da Pampulha, Belo Horizonte, MG. Ciênc Cult $1972 ; 24: 375$.

15. Carvalho OS, Guimarães CT, Massara CL, Bonésio JER. Situação atual da esquistossomose mansoni no lago da Pampulha, Belo Horizonte, MG, Brasil. Rev Saude Publica 1985; 19:270-277.

16. Freitas JR, Bedê LC, Marco Jr P, Rocha LA, Santos MBL. Population dynamics of aquatic snails in Pampulha Reservoir. Mem Inst Oswaldo Cruz 1987; 82 (Suppl IV):299-305.

17. Freitas JR, Santos MBL, Rocha LA. Situação atual da transmissão da esquistossomose na Pampulha - Ecologia dos moluscos da Represa. In: Seminário sobre a Bacia Hidrográfica da Pampulha, Belo Horizonte; 1992. p. 40-69.

18. Friese K, Schmidt G, Lena JC, Nalini Jr HA, Zachmann DW. Anthropogenic influence on the degradation of an urban lake - the Pampulha reservoir in Belo Horizonte, Minas Gerais, Brazil. Limnologica 2010; 40:114-125.

19. Pinto-Coelho RM, Santos S, Elias EC, Morais Jr CA, Fernandes DP, Fernandes GP, et al. Atlas da Qualidade de Água do Reservatório da Pampulha. Recóleo: Belo Horizonte; 2012.

20. LutzA. O Schistosomum mansoni e a schistosomatose, segundo observações feitas no Brazil. Mem Inst Oswaldo Cruz 1919; 11:121-155.

21. Pellegrino J, Siqueira AF. Técnica de perfusão para colheita de Schistosoma mansoni em cobaias experimentalmente infectadas. Rev Bras Malariol Doenças Trop 1956; 8:589-597.

22. Deslandes N. Técnica de dissecação e exame de planorbídeos. Rev Serv Esp Saúde Pub 1951; 4:371-382.

23. Paraense WL. Estudo atual da sistemática dos planorbídeos brasileiros. Arq Mus Nac 1975; 55:105-128.

24. Souza CP, Ribeiro PRB, Guimarães CT, Jannotti-Passos LK, Souza MA. Esquistossomose: nova ocorrência de Biomphalaria straminea em Belo Horizonte, Minas Gerais. Cad Saude Publica 1996; 12:541-544.

25. Massara CL, Carvalho OS, Caldeira RL, Jannotti-Passos LK, Schall VT. First report on the presence of Biomphalaria straminea in the municipality of Jaboticatubas, State of Minas Gerais, Brazil. Mem Inst Oswaldo Cruz 2002; 97 (supl I):27-29. 
26. Teles HMS. Distribuição geográfica das espécies dos caramujos transmissores de Schistosoma mansoni no Estado de São Paulo. Rev Soc Bras Med Trop 2005; 38:426-432.

27. Fernandez MA, Thiengo SC. Susceptibility of Biomphalaria straminea from Peixe Angical dam, Tocantins, Brazil to infection with three strains of Schistosoma mansoni. Mem Inst Oswaldo Cruz 2010; 105:488-491.

28. Souza CP, Pereira JP, Rodrigues MS. Atual distribuição geográfica dos moluscos hospedeiros intermediários do Schistosoma mansoni em Belo Horizonte, MG, Brasil. Mem Inst Oswaldo Cruz 1981a; 76:383-391.

29. Freitas JR, Santos MBL. Current advances on the study of snail-snail interactions, with special emphasis on competition process. Mem Inst Oswaldo Cruz 1995; 90:261-265.

30. Souza CP, Rodrigues MS, Araújo N. Suscetibilidade de Biomphalaria straminea (Dunker, 1848), de Belo Horizonte (MG), à infecção por cepas de Schistosoma mansoni. Rev Inst Med Trop São Paulo 1981b; 23: 188-193.

31. Pinto HA, Mati VLT, Melo AL. Dermatite cercariana por esquistossomatídeos de aves: É possível a ocorrência de casos no Brasil? Rev Patol Trop 2012; 41:1-14.

32. Souza CP, Araújo N, Carvalho OS, Freitas JR. Potencialidade de Biomphalaria tenagophila do Lago da Pampulha, Belo Horizonte, MG, como hospedeira do Schistosoma mansoni. Mem Inst Oswaldo Cruz 1987; 82:67-70.

33. Correa MCR, Coelho PMZ, Freitas JR. Susceptibilidade de linhagens de Biomphalaria tenagophila e Biomphalaria glabrata a duas cepas de Schistosoma mansoni - (LE-Belo Horizonte, MG e SJ-São José dos Campos, SP). Rev Inst Med Trop Säo Paulo 1979; 21:72-76.

34. Souza CP, Jannotti-Passos LK, Freitas JR. Degree of host-parasite compatibility between Schistosoma mansoni and their intermediate molluscan hosts in Brazil. Mem Inst Oswaldo Cruz 1995; 90:5-10.

35. Jannotti-Passos LK, Souza CP. Susceptibility of Biomphalaria tenagophila and Biomphalaria straminea to Schistosoma mansoni infection detected by low stringency polymerase chain reaction. Rev Inst Med Trop São Paulo 2000; 42:291-294

36. Souza CP, Azevedo MLL, Rodrigues MS, Pereira JP. Estudo comparativo da suscetibilidade de populações de Biomphalaria glabrata de Belo Horizonte (MG), à infecção com Schistosoma mansoni e a moluscicidas. Rev Inst Med Trop São Paulo 1982; 24:342-348.

37. Paraense WL. Planorbideos hospedeiros intermediários do Schistosoma mansoni. In: Cunha AS, editor. Esquistossomose mansoni. São Paulo: Ed. USP; 1970. p. 13-30.

38. Barbosa FS. Possible competitive displacement and evidence of hybridization between two Brazilian species of planorbid snails. Malacologia 1973; 14:401408.

39. Kawazoe U, Magalhães LA, Hotta LK, Takaku L. Competição biológica entre Biomphalaria glabrata (Say, 1818) e Biomphalaria tenagophila (d' Orbigny, 1835) em criadouros naturais no município de Ourinhos, SP (Brasil). Rev Saude Publica 1980; 14:65-87.

40. Barbosa FS. New field observations on the competitive displacement between two species of planorbid snails inhabiting Northeastern Brazil. Mem Inst Oswaldo Cruz 1981; 76:361-366.

41. Barbosa FS. Competitive displacement of Biomphalaria glabrata by B. straminea. Mem Inst Oswaldo Cruz 1987; 82 (supl IV):139-141.

42. Barbosa CS, Barbosa FS, Arruda F. Long-term controlled field experiment on the competition between two species of Biomphalaria (Mollusca, Basommatophora), the snail vectors of Schistosoma mansoni in Northeastern Brazil. Cad Saude Publica 1993; 9:170-176.

43. Giovaneli A, Silva CLPAC, Leal GBE, Baptista DF. Habitat preference of freshwater snails in relation to environmental factors and the presence of the competitor snail Melanoides tuberculatus (Müller, 1774). Mem Inst Oswaldo Cruz 2005; 100:169-176.

44. Pointier JP, David P. The Biological Control of the Snail Hosts of Schistosomes: The Role of Competitor Snails and Biological Invasions. In: Toledo R, Fried B, editors. Biomphalaria Snails and Larval Trematodes. New York: Springer; 2011. p. 215-238.

45. Combes C. Trematodes: antagonism between species and sterilizing effects on snails in biological control. Parasitology 1982; 84:151-175.

46. Esteban JG, Muñoz-Antoli C, Trelis M, Toledo R. Effects of nonschistosome larval trematodes on Biomphalaria snails. In: Toledo R, Fried B, editors. Biomphalaria Snails and Larval Trematodes. New York: Springer; 2011. p. $127-158$.

47. Souza CP, Lima LC, Jannotti-Passos LK, Ferreira SS, Guimarães CT, Vieira IBF, et al. Moluscos límnicos da microrregião de Belo Horizonte, MG, com ênfase nos vetores de parasitoses. Rev Soc Bras Med Trop $1998 ; 31: 449-456$

48. Enk MJ, Amorim A, Schall VT. Acute schistosomiasis outbreak in the metropolitan area of Belo Horizonte, Minas Gerais: alert about the risk of unnoticed transmission increased by growing rural tourism. Mem Inst Oswaldo Cruz 2003; 98:745-750.

49. Enk MJ, Caldeira RL, Carvalho OS, Schall VT. Rural tourism as risk factor for the transmission of schistosomiasis in Minas Gerais, Brazil. Mem Inst Oswaldo Cruz 2004; 99 (Suppl 1):105-108.

50. Massara CL, Amaral GL, Caldeira RL, Drummond SC, Enk MJ, Carvalho OS. Esquistossomose em área de ecoturismo do Estado de Minas Gerais, Brasil. Cad Saude Publica 2008; 24:1709-1712.

51. Celso Filho A, Moreira CA, Santos E, Carsalade FL, Alves GM, Ricarte IG, et al. Consórcio de Recuperação da Bacia da Pampulha [Internet]. Available at: http://www.recuperacaobaciapampulha.com.br. 2012.

52. Von Sperling E. Community response to the restoration of an urban lake. In: Water, Sanitation and Hygiene: Challenges of the Millennium. Bangladesh: WEDC Conference, 2000. p. 123-125. 